\title{
SOME INSTRUMENTS USED TO ACHIEVE ENVIRONMENTAL PERFORMANCE IN TOURIST ACCOMMODATION UNITS
}

\author{
Mirela Ștefănică \\ Faculty of Economics and Business Administration, Al.I. Cuza University of Iaşi \\ stefanica_mirela@yahoo.com
}

\begin{abstract}
The paper highlights some instruments that help us to achieve environmental performance in tourist accommodation structures. The most known instruments used to achieve environmental performance are as follows: ISO 14001 standards (Environmental Management Standard), EMAS (European Eco-Management and Audit Scheme), and EU ECOLABEL. With the help of these instruments, we can identify and quantify the material and power resources consumed, the emissions and waste generated, we can evaluate their potential impact over the environment, and we can identify the options to reduce these impacts. The reasons at the basis of the creation of these instruments are extremely complex, going beyond the purely economic frame in order to enter an ethical sphere of debates inciting the spirit of almost all the population on the Globe, which is the type of planet that we leave as inheritance to our followers, the future generations. According to the reports of the European Commission regarding these instruments we have shown the evolution and the present situation of EMAS registrations and EU Ecolabel for European tourist accommodation services.
\end{abstract}

Keywords

Environmental performance; tourist accommodation; ISO 14001; EMAS; EU Ecolabel

JEL Classification

Q53; L83; M10

\section{Introduction}

Generally accepted, performance represents a special achievement in a certain field of activity. Performance is defined as: the art of good businesses, the way to use the best possible part of company resources in order to reach the objectives of the organisation (Bessire, 1999), a state of competitiveness of the organisation, reached by a degree of efficacy and efficiency which ensure a sustainable presence on the market (Niculescu \& Lavalette, 1999), a special result obtained in the field of management, economy, commerce, etc., imprinting characteristics of competitiveness, efficiency, and efficacy to the organisation and to its process and structural components (Verboncu \& Zalman, 2005, Roman et al., 2015). Performance means success, competitiveness, accomplishment, action, continuous effort, also optimisation of present and projection of future (Harrington \& Harrington, 2000), and it consists of reaching the purposes in convergence with the orientation of the company (Noyé, 2002). According to Drucker (2006), performance has two components: efficacy, which represents the ability to establish and to accomplish the adequate objectives, and efficiency, which represents the ability to optimally use the available resources for achieving the objectives. According to the Explanatory Dictionary of Romanian Language (1996), performance is a special result, obtained in a certain field of activity. This definition, with no economic or managerial implications, means that performance cannot be associated with any result obtained, only with a special one. What does "special" mean? First, it 
means highly superior to what was previously obtained; second, it means superior to the results obtained by "others" (competitors, etc.), and third, it means different from the objectives favourably assumed. According to Oxford English Dictionary (2017), performance is given by the quality of performing an action, operation, or process. It also represents the competence or efficiency of a person or thing in performing an activity. From a psychological point of view, according to the same dictionary, performance is given by a person's noticeable or measurable behaviour in a certain situation, usually an experiment. In business, performance is given by the degree of profitability of an investment (Pădurean et al., 2014). Performance deals with several concepts as: successful management, successful organisation, successful activity, performance criteria, performance management. The fields where performances could have an impact are as follows: managerial performances, economic performances, financial performances, social performances, technical and technological performances, commercial performances, regional economic performances, environmental performances (Porter, 2003).

The concept of environmental performance belongs to Hobincu (2004), and refers to the measurable results of the environmental management system, related to the control of the organisation over its environmental problems, based on its environmental policy, general objectives, and specific objectives (Popescu et al., 2016). According to Țigu \& Călărețu, (2013), there is an evolutional process in the corporations regarding the integration of environmental aspects in complex strategic plans. Including the environmental problems and sustainable development among the main concerns of the great general planning needs an increased responsibility, the environmental audit gaining credibility. Therefore, we consider that a powerful audit programme for an active environmental management is essential. A concept used, introduced and approached by Duțescu et al. (2014) is performance in relation with society and the environment. This is a concept which needs a good management frame, which on one hand associates social management and environment with competitive strategy and business management, and on the other hand integrates environment and social information with business economic information and reporting to sustainability.

Achieving environmental performance in tourism does not mean only to observe the minimum standards of environmental protection (Popescu et al., 2014), it also refers to adopting the best practices, accreditation schemes, ethical codes, environmental certifications (Honey\&Rome, 2001). According to Brotherton (2004), environmental performance as a success factor has a competitive lever effect on which the resources of an organisation should focus. In hotel industry, Israeli et al. (2006) propose a model for performance evaluation, based on several aspects: financial, specific to the sector, of marketing, regarding customer's satisfaction, human resources (employees and managers), quality employees (abilities and knowledge), and productivity of their work, quality management and managers' productivity, hotel efficiency and hotel strategic assets. The studies performed by other specialists in the field of tourism highlighted the following success factors: personal involvement, personnel welfare and training, quality food and services, money as a value, marketing activities and comparative evaluation with the best practices (Bergin, 2003); strategy of economic development, of cost management, need to gain new customers and to maintain the existing ones, monitoring competitors' activity, efficient management of the assets, efficient management of the personnel, encouragement of innovation (Flanagan, 2005); profitability, budget control, quality of services, management of the relationship with the customers, customer's profile, clarity of objectives, investments in personnel, productivity and personnel as drivers of innovation and teamwork (Nica, 2010); profitability, maintaining the customers, their satisfaction, evaluation of efficiency and innovation (O’Donoghue \& Luby, 2006); service improvement, focus on customer and 
services, creative use of technologies, development of basic capacities (Kandampully, 2006).

After analysing the literature, we could see that in the field of tourism the emphasis is on the economic and social performance, and less on the environmental one. In comparison to most studies, we intend to pay more attention to the instruments leading to the environmental performance, because it would be a more original approach, and it would show new aspects. In addition, it would help to the improvement of hotel business quality, to economic and social performance, ensuring a sustainable future.

\section{Instruments used to achieve environmental performance}

The most known instruments used to achieve environmental performance are as follows: ISO 14001 standards (Environmental Management Standard), EMAS (European Eco-Management and Audit Scheme), and EU ECOLABEL. The reasons at the basis of the creation of these instruments are extremely complex, going beyond the purely economic frame in order to enter an ethical sphere of debates inciting the spirit of almost all the population on the Globe, which is the type of planet that we leave as inheritance to our followers, the future generations.

\section{ISO 14001 standard of environmental management}

The creation of an environmental management system in a tourist unit is a complex process involving several stages. First of all, the environmental policy, synthetically presented in figure 1, is a public document, describing the measures to be taken in the tourist unit for environmental protection.

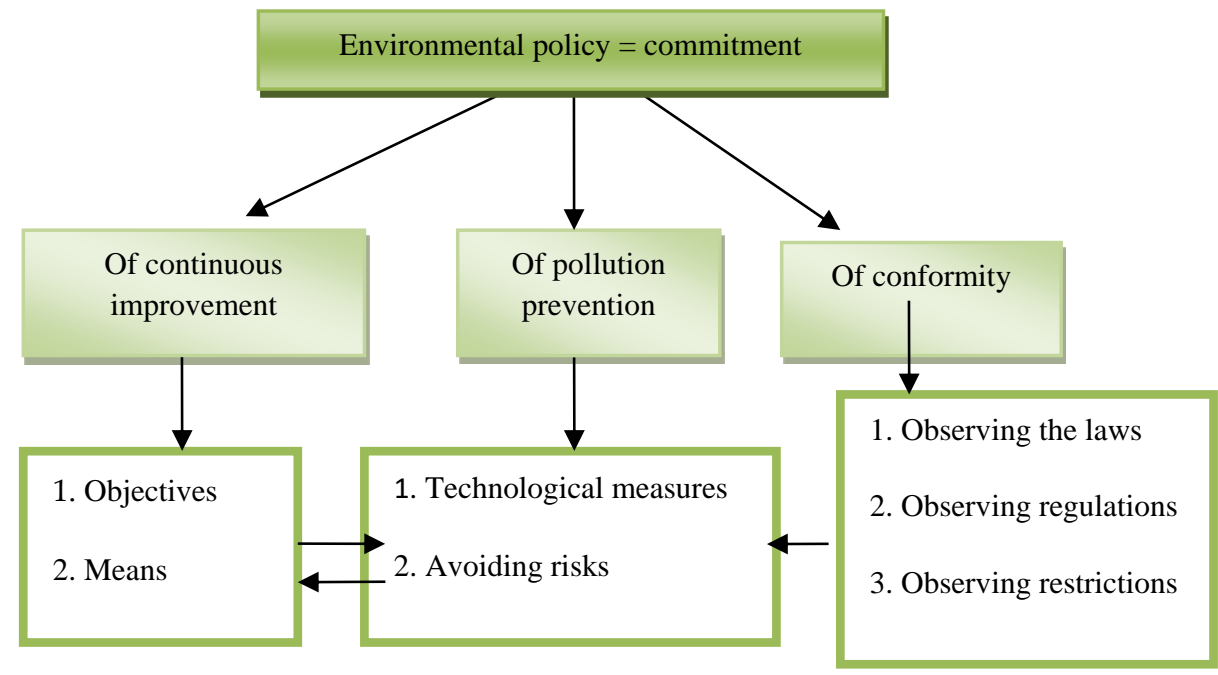

Figure 1 Environmental policy

Source: Hobincu, R.V.,(2004) Politica de mediu şi crearea sistemelor de management de mediu, Bucharest: Perfect

This commitment, made by the managers of a tourist unit, must be based on the following: examination and surveillance of the activity developed in tourist units, and analysis of critical points for the environment; taking measures for reducing, preventing, and eliminating environmental pollution; preliminary evaluation of the impact of new activities and products over the environment; prevention or reduction of 
risks of pollutant substance emissions and of power waste; regularly comparing the programme of environmental action with the environmental policy; systematic performance of environmental objectives; cooperation with authorities for minimisation of the environmental risks, with the help of adequate techniques; sensitisation and eco-awareness of the employees of tourist unit; informing the tourists about the dangers of the products and services towards the environment; obligation of suppliers and subcontractors to observe the environmental norms and regulations applied within the tourist unit; total information of the public, and an open dialogue about the impact of the tourist unit over the environment.

Environmental management systems according to standard ISO 14001 have a systemic, dynamic approach, based on the principle of continuous improvement. They rely on Deming cycle (figure 2), and involve mainly the identification of the causes in order to act accordingly for stopping or at least for reducing the negative effects over the environment.

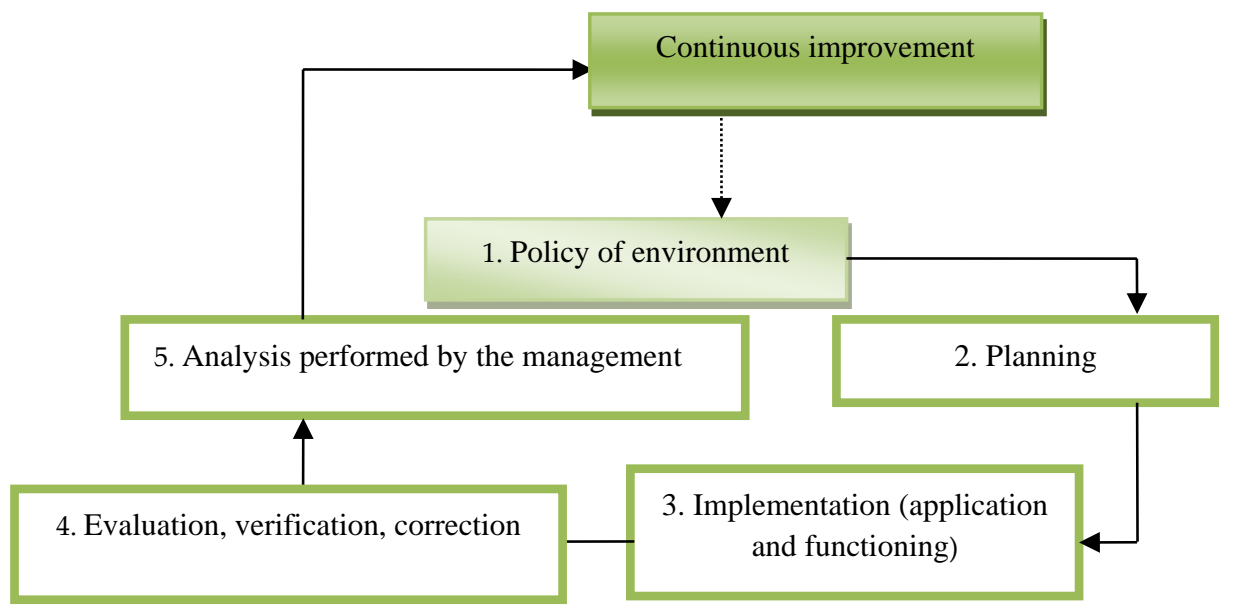

Figure 2 Deming cycle

Source: Author

This model of quality management system, also known as PDCA (Plan - Do - Check - Act) has an emphasis on organisational change and innovation, in order to ensure a sustainable business performance.

\section{European Eco-Management and Audit Scheme (EMAS)}

EMAS has the purpose to promote the continuous improvement of environmental performance by the development and implementation of the Environmental Management System (EMS), evaluation of environmental performances by auditing and offering information related to environmental performances to the interested public.

According to the Report of the European Commission of April 2018 regarding EMAS registrations, in Europe there were 12870 companies, institutions, and public authorities developing their activity under EMAS coordination, i.e. over 2.6 million people of 3866 organisations. In figure 3 we present the evolution of EMAS registrations between 2010 and 2018. 


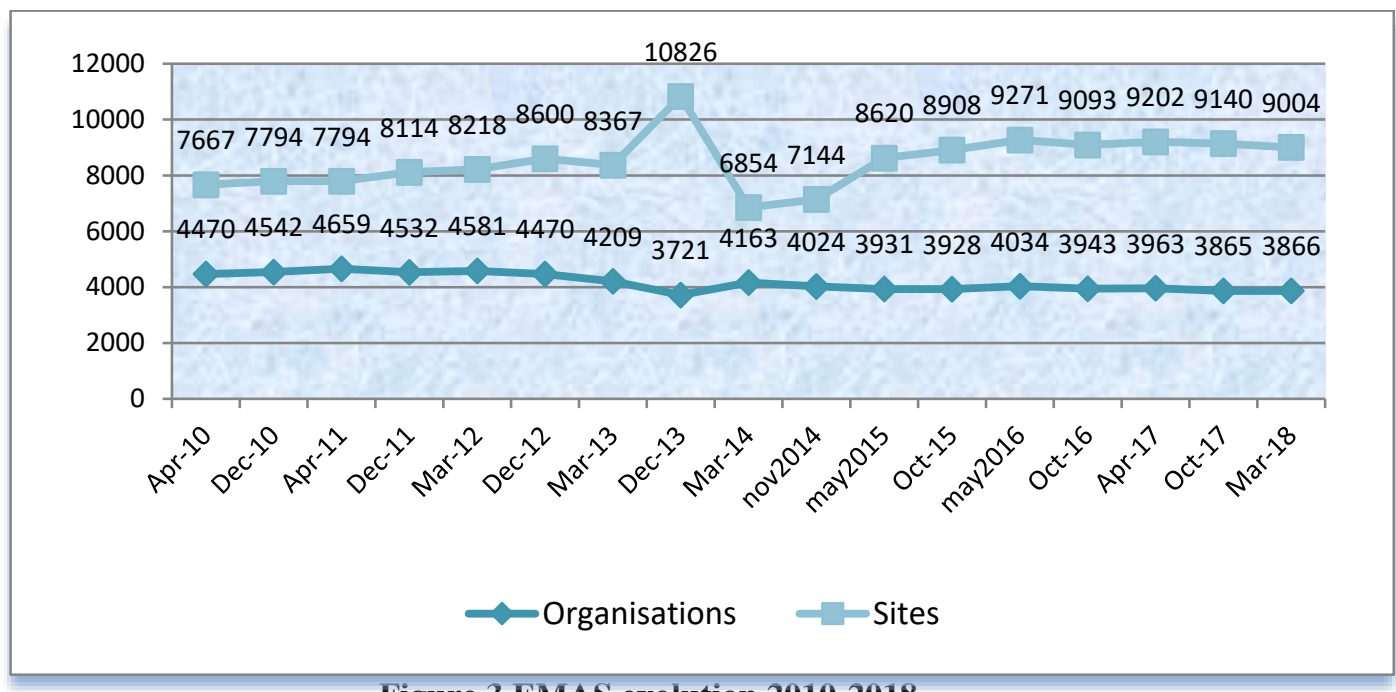

\section{Figure 3 EMAS evolution 2010-2018}

Source: http://ec.europa.eu/environment/emas/emas_registrations/statistics_graphs_en.htm

In general, there was a constant evolution of EMAS registered organisations and units between 2010 and 2013. EMAS registered units presented an important increase in the last 3 trimesters of the year 2013, followed by a decrease in the first trimester of the year 2014. Since then up to May 2016 there was an improvement of the situation. According to the information given by the European Commission, we can see that Germany and Italy are the countries with the highest number of EMAS registrations.

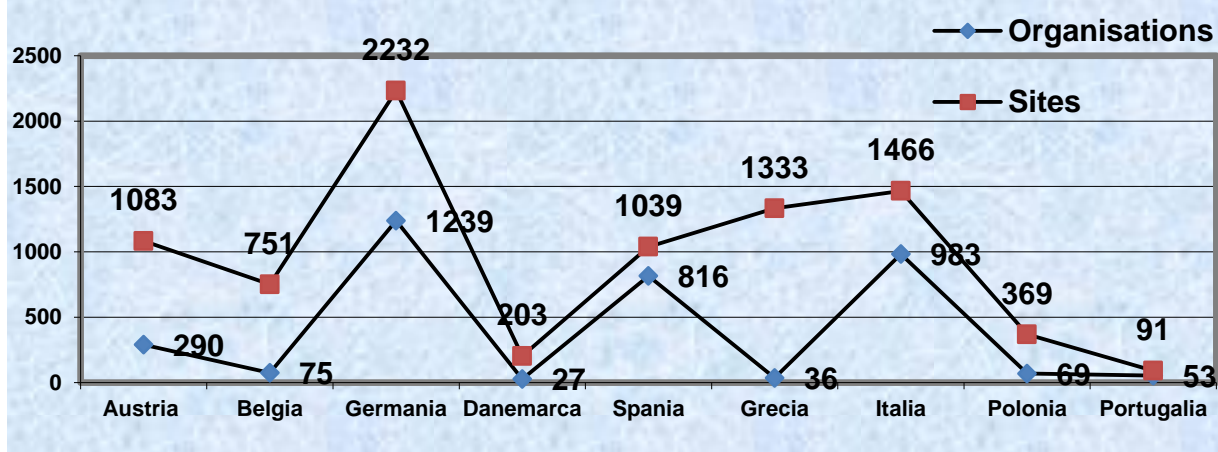

Figure 4 Top of European countries with the highest number of EMAS registrations (2018)

Source:http://ec.europa.eu/environment/emas/emas_registrations/statistics_graphs_en.htm

Regarding EMAS distribution in the sector of services, most registrations are in the fields of waste and disposal and public administration, while tourist accommodation services hold the $4^{\text {rd }}$ place, with 185 registrations (figure 5). 


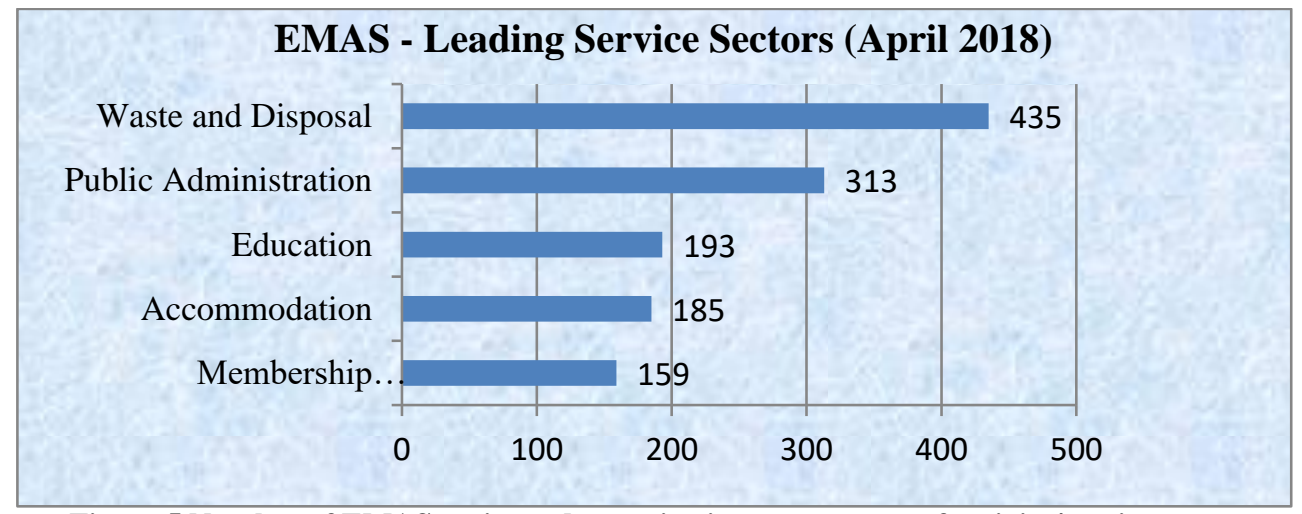

Figure 5 Number of EMAS registered organisations per sectors of activity/services

Source:http://ec.europa.eu/environment/emas/emas_registrations/statistics_graphs_en.htm

Consequently, from the 185 EMAS registrations for accommodation services, Germany, Spain, and Italy are the countries with the highest number of registrations (figure 6).

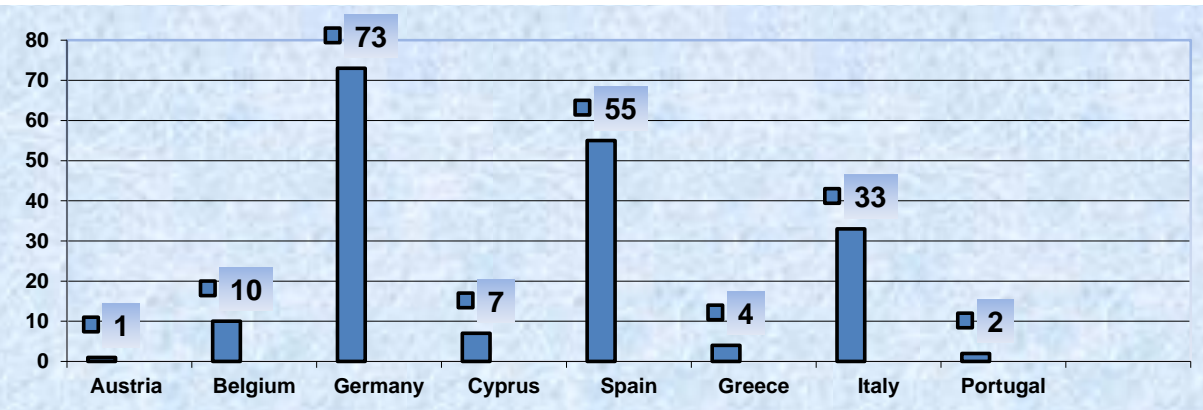

Figure 6 EMAS for accommodation services per countries (2018)

Source:http://ec.europa.eu/environment/emas/emas_registrations/statistics_graphs_en.htm

\section{EU Ecolabel}

The European Ecological Label, EU Ecolabel, is another instrument used to achieve environmental performance. It is granted to the products which are in accordance with certain ecological criteria established at European level. The criteria were identified based on complete scientific studies regarding the aspects related to the entire products/services life cycle, they are available for 3-5 years, and they are reviewed regularly to consider the technical progress. 


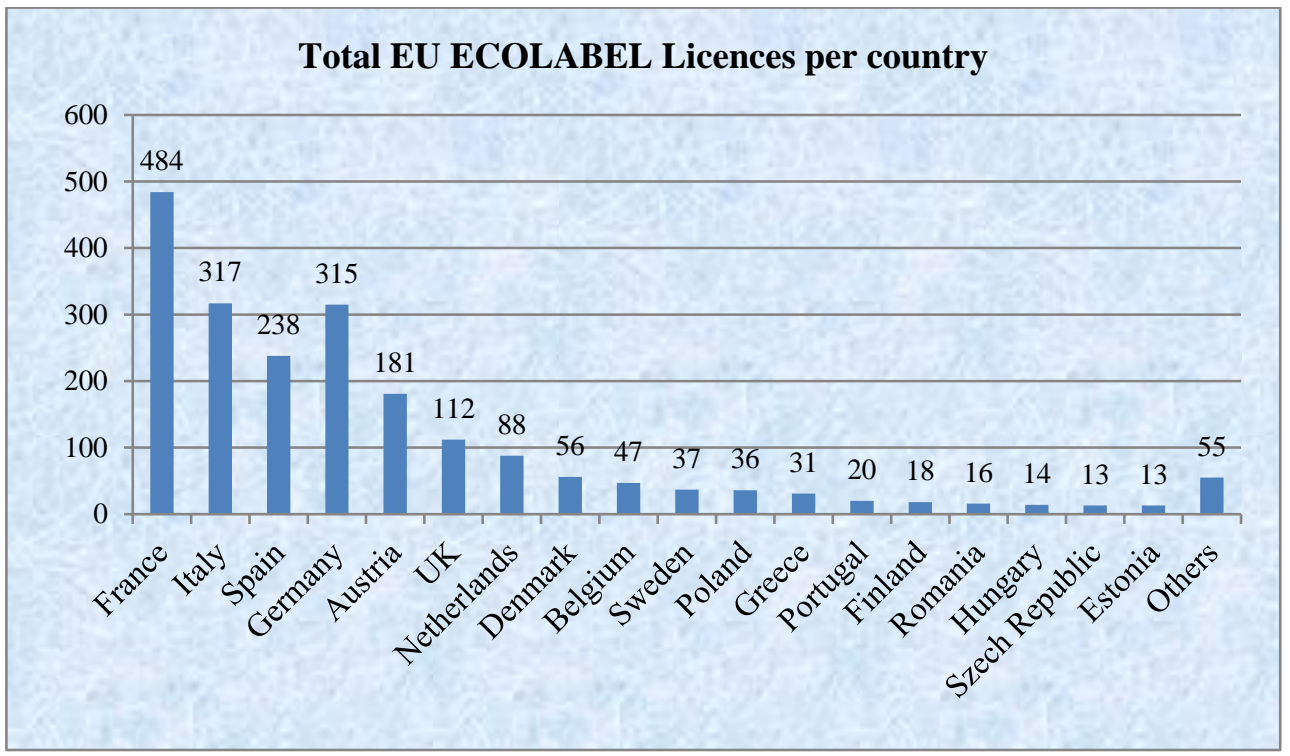

Figure 7 EU Ecolabel per countries and number of products and services (2018)

Source:http://ec.europa.eu/environment/ecolabel/facts-and-figures.html

With the help of this instrument, we can identify and quantify the material and power resources consumed, the emissions and waste generated, we can evaluate their potential impact over the environment, and we can identify the options to reduce these impacts. The Report of the European Commission presented in March 2018 shows that 53\% of the European ecolabels are owned by France 23\%, $15 \%$ by Italy, and $15 \%$ by Germany. The situation of European ecolabel per groups of products and services in the present is shown in figure 8 .

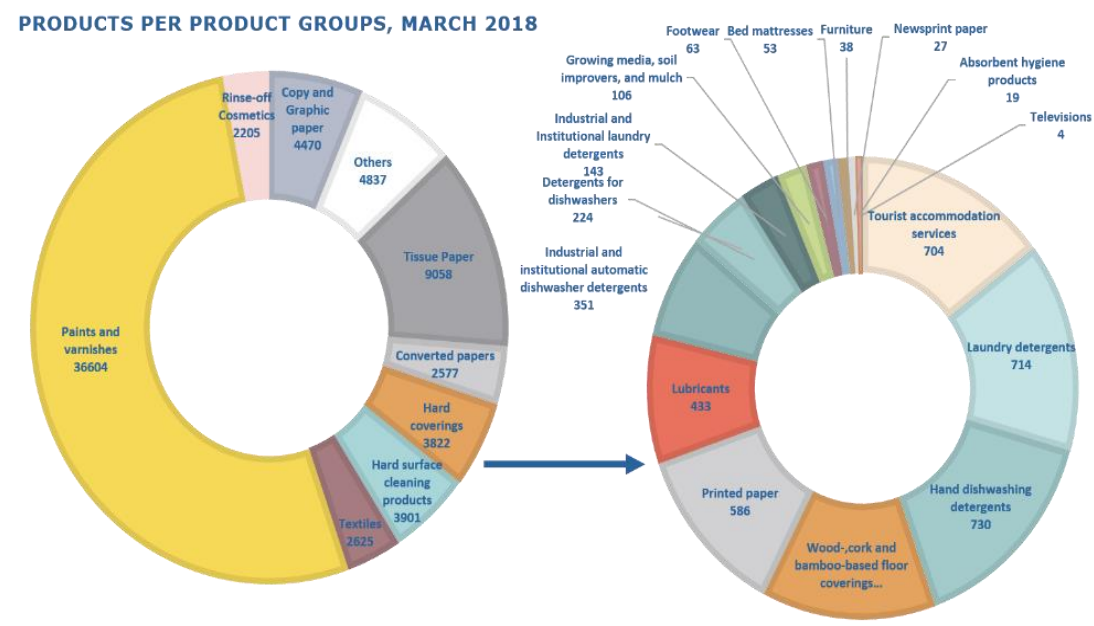

Figure 8 EU Ecolabel per groups of products and services (2018)

Source: http://ec.europa.eu/environment/ecolabel/facts-and-figures.html

The number of European ecolabels attributed to tourist accommodation services registered an ascending trend from 616 in September 2014 to 704 in March 2018. There are 397 hotels with EU Ecolabel, of which 156 are in Italy. In figure 9 we presented 
the situation of the eco-labelled tourist accommodation services in Europe in 2018, for the countries with more than two European ecolabels.

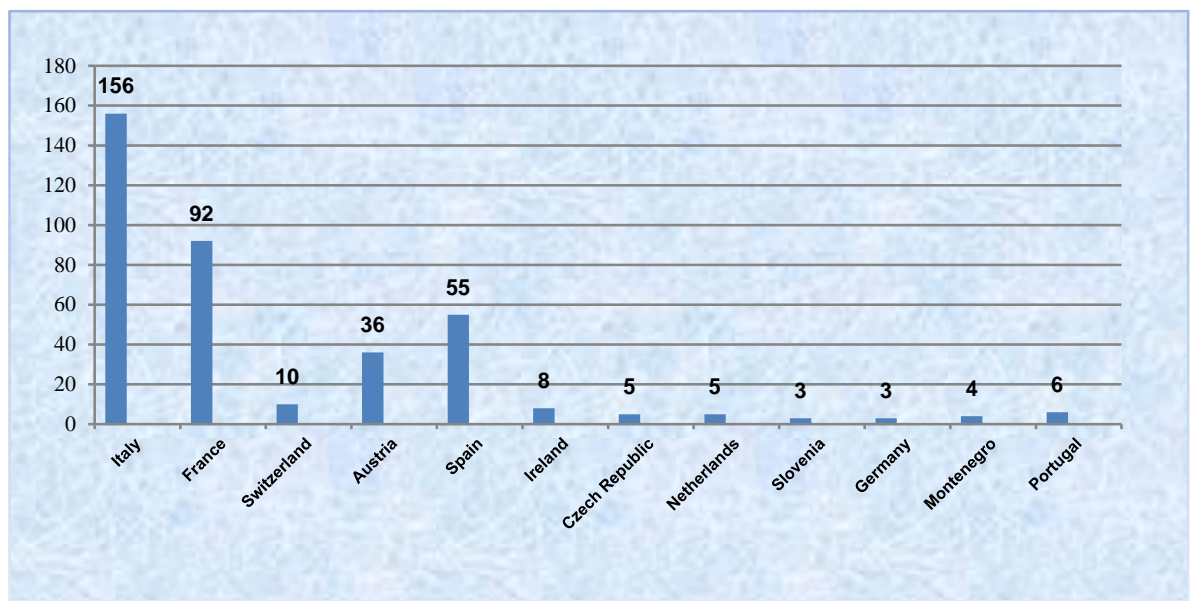

Figure 9 Situation of eco-labelled tourist accommodation services in Europe (2018)

Source: http://ec.europa.eu/ecat/hotels/en/list

As we can see, Italy is the country with the highest number of eco-labelled accommodation structures.

At international level there are several recognised certification and eco-labelling programmes, offering labels or awards conceived to show that environmental, socialcultural, and economic practices of these tourist areas meet higher criteria.

\section{Conclusions}

Specialty studies highlight the fact that performance is a basic concern of researchers from the economic-social field. On the other hand, there is an increased awareness among the managers concerning the need to optimise the efficiency of operational activities and of business decision making, like those regarding profit, planning, control, and continuous improvement of performance, with the purpose to obtain a competitive advantage. This leads to an increase of solid management practices, with an emphasis on performance management. An economy based on performance and sustainability, obtained individually or by cooperation, leads to favourable results horizontally, vertically, multidimensionally, endogenously, and exogenously. This is the context in which environmental management becomes a component of the managerial function, also in tourism, activated by certifications and registrations reflecting their interest in the operators' environment.

In conclusion, certification, registration, or owing an ecolabel, as well as adopting the best practices by the hotel management represents the best way to show the guests the concern and the efforts of the organisation regarding the achievement of environmental performance, as well as the improvement of quality, because tourists will surely see environmental performance as higher quality.

\section{References}

Bergin, B. (2003), Restaurant Critical Success Factors and Inhibitors. Hotel and Catering Review Journal. March. Dublin. 
Bessire, D. (1999), Définir la performance, Contabilité, Contrôle, Audit, vol.2.

Brotherton, B. (2004) Critical Success Factors in UK Corporate Hotels. The Service Industries Journal, Vol. 24, No. 3, pp 19-42.

Dicționarul Explicativ al Limbii Române (1996), Bucharest: Științifică și Enciclopedică, p. 778.

Drucker, P. (2006), Despre profesia de manager, Bucharest: Meteor Press.

Dutescu, A., Popa, A.F., Ponorîca, A.G. (2014), Sustenabilitatea în industria turismului, bazata pe indicatorii cheie de performanta, Amfiteatru Economic Volum: 16, nr. Special 8/2014, pp 830 - 844.

Flanagan, C. (2005), An Investigation into the Performance Measurement Practices of Irish Hotel Groups. Dublin Institute of Technology, Dublin.

Harrington, H.J., Harrington, J.S. (2000), Management total în firma secolului XXI, Bucharest: Teora.

Hobincu, R.V. (2004), Politica de mediu şi crearea sistemelor de management de mediu, Bucharest: Perfect.

Honey, M., Rome, A. (2001), Protecting Paradise: Certification Programs for Sustainable Tourism and Ecotourism, Washington: Institute for Policy Studies.

Israeli, A., Barkan, R., Fleishman, M. (2006), An Exloratory Approach to Evaluating Performance Measure: The Manager's Perspectives, The Service Industries Journal, pp 861-872.

Kandampully, J., (2006) The New Customer-Centred Business Model for the Hospitality Industry., International Journal of Contemporary Hospitality Management. Vol. 18 No. 3, pp 173-187.

Nica, P., (2010), Managementul performanţelor resurselor umane, Iași: Sedcom Libris. Niculescu, M., Lavalette, G. (1999) Strategii de creștere, Bucharest: Economică.

Noyé, D. (2002), Manager les performances, INSEP CONSULTING editions, Paris, p. 6.

O’Donoghue, D., Luby, A., (2006), Management Accounting for the Hospitality, Tourism and Retail Sectors. Blackhall Publishers: Dublin.

Oxford English Dictionary, [online] Available at: http://www.oed.com/view/Entry/140783\#eid0 (accessed 29 September 2017).

Pădurean, M.A., Nica, A.M., Nistoreanu, P. (2014), Entrepreneurship in tourism and financing through the Regional Operational Programme, Amfiteatru Economic,17(38), pp. 183-197.

Popescu, C., Bostan, I., Robu, I.B., Maxim, A., Diaconu (Maxim), L., (2016), An Analysis of the Determinants of Entrepreneurial Intentions among Students: A Romanian Case Study, Sustainability 8(8), 771; doi:10.3390/su8080771, Available online: http://www.mdpi.com/2071-1050/8/8/771/htm (accessed on 15 December 2017).

Popescu, C.R., Popescu, V.A., Popescu, G.N., (2014), The entrepreneur's role in the performance growth of the financial audit activity in Romania, Amfiteatru Economic, 17(38), pp. 232-251.

Porter, M. (2003), The economic performance of regions, Regional Studies, Vol. 37.6\&7, pp. 549-578, August/October 2003, [online] Available at: http://dx.doi.org/10.1080/0034340032000108688> (accessed 10 May 2018).

Roman, T., Bostan, I., Manolică, A., Mitrica, I., (2015), Profile of Green Consumers in Romania in Light of Sustainability Challenges and Opportunities, Sustainability, 7, 6394-6411; doi:10.3390/su7066394, Available online: http://www.mdpi.com/2071-1050/7/6/6394/htm (accessed on 15 December 2017). 
Țigu, G., Călărețu, B., (2013), Performanţele Supply Chain Management în turism. Studiu de caz la S.C. Continental Hotels S.A., Amfiteatru Economic, XV (33), pp. 60-73.

Verboncu, I., Zalman, M. (2005), Management și performante, Bucharest: Universitară.

European Commission, (2018), Eco-Management and Audit Scheme, Statistics \& graphs, Available online: http://ec.europa.eu/environment/emas/emas_registrations/statistics_graphs_en. htm (accessed on 21 September 2018).

European Commission, (2018), Eco-Management and Audit Scheme, Reports \& statistics, Available online: http://ec.europa.eu/environment/emas/register/reports/reports.do (processed data) (accessed on 21 September 2018).

EMAS Registered Accommodation, (2018), Available online: http://ec.europa.eu/environment/emas/pdf/other/EMAS_Accommodation_201 8.pdf (processed data) (accessed on 21 September 2018).

European Commission, (2018), Environment, Ecolabel, Facts and Figures, Statistical Overview, Available online: http://ec.europa.eu/environment/ecolabel/factsand-figures.html (accessed on 21 September 2018).

European Commission, (2018), The EU Ecolabel Tourist Accommodation Catalogue, Available online: http://ec.europa.eu/ecat/hotels/en/list - processed data, (accessed on 21 September 2018). 